\title{
Workshop Pembuatan Mini Konveyor Untuk Proses Quality Control Berbasis Computer Vision
}

\author{
Chaerur Rozikin ${ }^{1)}$, ${ }^{*}$ Ultach Enri ${ }^{2)}$, Aries Suharso ${ }^{3)}$, Kusnadi $^{4)}$ \\ ${ }^{1), 2), 3)}$ Program Studi Teknik Informatika, Fakultas Ilmu Komputer Universitas Singaperbangsa Karawang \\ ${ }^{4)}$ Program Studi Teknik Industri, Fakultas Teknik, Universitas Singaperbangsa Karawang
}

Correspondence author: ultach@staff.unsika.ac.id

Received : 2 Agustus $2021 \quad$ Accepted : 24 September $2021 \quad$ Published: 30 September 2021

DOI: https://doi.org/10.37012/jpkmht.v3i2.629

\begin{abstract}
ABSTRAK
Seiring berjalannya waktu, teknologi yang ada juga berkembang, perkembangan teknologi akan membantu manusia dalam kesehariannya. Otomatisasi adalah suatu teknologi yang terkait dengan mekanik, elektronik, dan komputer berdasarkan sistem untuk beroperasi dan untuk mengontrol produksi. Otomatisasi dapat digunakan dalam proses Quality Control dengan menggunakan Konveyor dengan Sensor hc05. Dengan sistem otomasi ini, proses Quality Control akan lebih cepat dan mengurangi tenaga kerja manusia di dalamnya. Cara kerjanya adalah dengan menyensor botol di dalam kotak untuk melihat jumlah botol dalam kotak sesuai dengan angka yang telah ditentukan.
\end{abstract}

Kata Kunci: Kualitas Kontrol, Otomasi, Sistem Komputer Vision.

\begin{abstract}
As time goes by, the existing technology also develops, the development of technology will help humans in their daily lives. Automation is a technology related to mechanical, electronical, and computer based on system to operate and to control the production. Automation can be used in the Quality Control process using a Conveyor with a hc05 Censor With this automation system, the Quality Control process will be faster and reduce the human labor in it. The way it works is by censoring the bottles inside the box to see the number of bottle in the box according to a predetermined number.
\end{abstract}

Keywords: Quality Control, Automation, Hc05 Censor 


\section{PENDAHULUAN}

Teknologi pada saat ini berkembang dengan sangat pesat. Berkembangnya ilmu teknologi bertujuan untuk membantu pekerjaan yang dilakukan oleh manusia sehingga membuat pekerjaan tersebut menjadi lebih mudah dan cepat (Guntoro, 2020). Ilmu pengetahuan dan teknologi saat ini sangat berkembang terutama pada industri kecil, keduanya menjadi faktor penting dalam meningkatkan kesejahteraan masyarakat. Seiring berjalannya waktu kemajuan teknologi masyarakat lebih sering menggunakan sistem otomasi dalam kehidupannya seharihari terutama pada dunia usaha atau indutri kecil. (Dewantara \& Kholil, 2017).

Penggunaan otomasi ini berguna untuk mengefesiensi waktu serta menghemat energi (Oktariawan dkk., 2013). Otomasi bisa digunakan untuk mengendalikan produksi yang operasinya terkait dengan aplikasi mekanik, elektronik, dan komputer didasarkan oleh (Dewantara \& Kholil, 2017). Dengan adanya otomasi akan mempermudah proses produksi sehingga dapat meningkatkan kualitas dan kuantitas produk yang akan dihasilkan. Teknologi otomasi yang diterapkan di industri kecil dan menengah berkaitan dengan pengurangan keterlibatan tenaga manusia dalam beberapa proses produksi (Rachmat dkk., 2014). Dilakukannya sistem otomasi karena bisa meningkatkan produktivitas perusahaan, mengurangi biaya tenaga kerja, kurangnya keahlian tenaga kerja, meningkatnya kualitas produk untuk itu sistem otomasi perlu dilakukan dalam sebuah perusahaan atau industri (Santoso dkk., 2013).

Untuk mendukung sistem otomasi, pada sistem otomasi industri dibutuhkan sensor didalamnya sebuah sensor dapat memberikan informasi mengenai posisi suatu objek (Limantara dkk., 2017). Selain itu sensor digunakan untuk mendekteksi objek (Rosi, 2017). Penggunaan sensor tersebut digunakan untuk mengubah besaran bentuk menjadi besaran listrik yang akan diteruskan ke dalam pemprosesan untuk dirangkai dengan perangkat lainnya menjadi sistem digital (Jahary dkk., 2019).

Otomasi dalam proses Quality Control dilakukan dengan menggunakan mini konveyor berbasis komputer vision. Dengan sistem otomasi tersebut akan mempermudah industri kecil dalam proses quality control. Proses quality control merupakan salah satu proses yang peting dalam suatu produksi. Pada proses quality control dilakukannya pengecekan untuk mempertahankan kualitas dan barang-barang yang dihasilkan sehingga dapat memberikan kepuasan kepada pelanggan (Wardani, 2015). Untuk menjalankan proses quality control berbasis komputer vision membutuhkan sebuah konveyor. Digunakannya konveyor untuk 
memindahkan bahan produksi ataupun hasil produksi yang biasa digunakan oleh sebuah industri atau perusahaan (Utomo dkk., 2019).

Tujuan penelitian ini adalah untuk Quality Control yaitu untuk proses pengecekan jumlah botol dalam kardus sudah sesuai dengan jumlah yang ditentukan atau belum sesuai. Keuntungan dari sistem otomasi ini bisa mempercepat proses quality control dan tidak menggunakan tenaga manusia didalamnya.

\section{METODE PELAKSANAAN}

Untuk merealisasikan program ini berikut merupakan atau langkah-langkah pembuatan mini Konveyor diantaranya :

1. Membuat rancangan design mini konveyor dengan mengguakan aplikasi Sketchup serta menentukan ukuran tiap penyusun Konveyor. Berikut merupakan design mini konveyor beserta ukurannya.

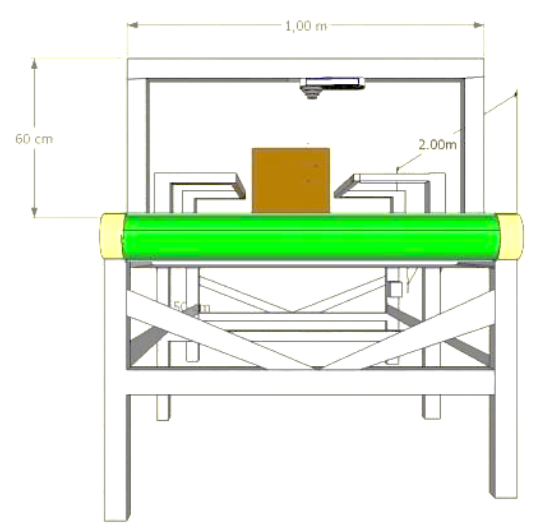

Gambar 1. Design mini konveyor

2. bahan dan alat yang akan digunakan dalam pembuatan Konveyor diantaranya baja ringan, paralon, tutup paralon,baut,belt, karpet Konveyor, gergaji, dan gerinda

3. Potong baja ringan sesuai dengan ukuran yang telah ditetapkan, untuk membuat rangka mini konveyor yaitu dengan memasang 3 kaki baja ringan ke sebelah kanan kiri di badan dan disanggah dengan 3 baja ringan sehingga akan terbentuk rangka mini konveyor. 


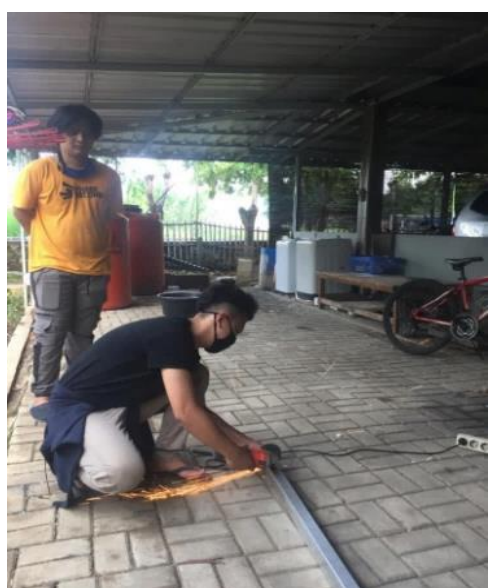

Gambar 2. Pemotongan Besi Ringan

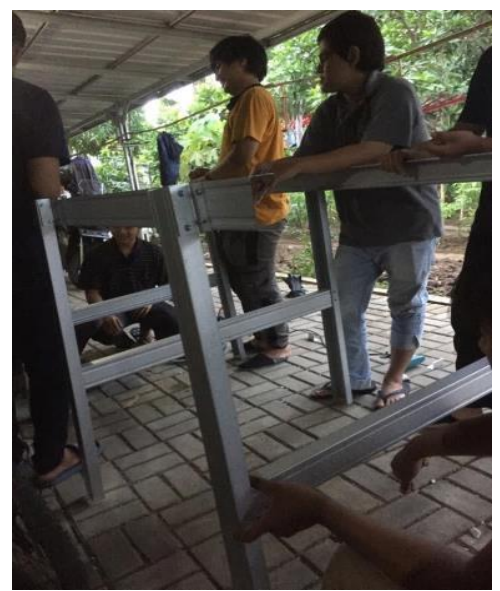

Gambar 3. Pembuatan Rangka Badan Konveyor

4. Potong 3 buah paralon sesuai dengan ukuran yang sudah ditetapkan setelah itu paralon ditutup dengan menggunakan plok shock. Pasangkan bearing pada plok shock untuk menyambungkan paralon dengan rangka Konveyor.

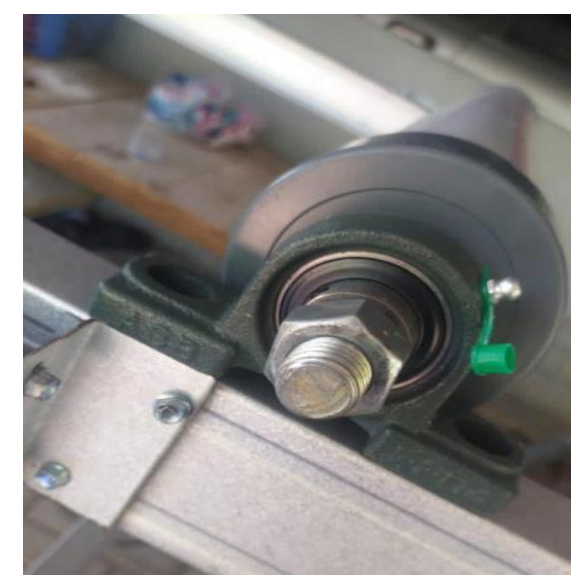

Gambar 4 (a). Pemasangan Bearing

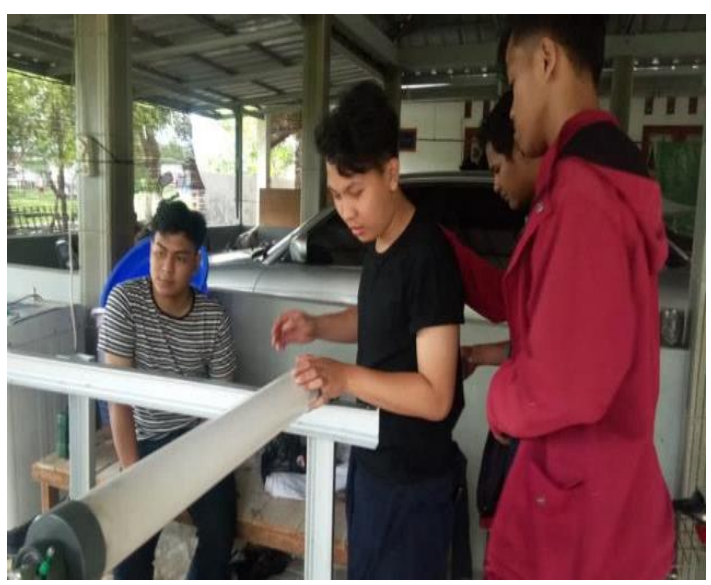

Gambar 4 (b). Perakitan Pipa ke Badan Konveyor

5. Pasang pull dan generator untuk memutar mini konveyor pada baut yang sudah dipasang ke plok shock, lalu kaitkan dengan $v$-belt dan sambungkan dengan generator yang telah dipasang. 


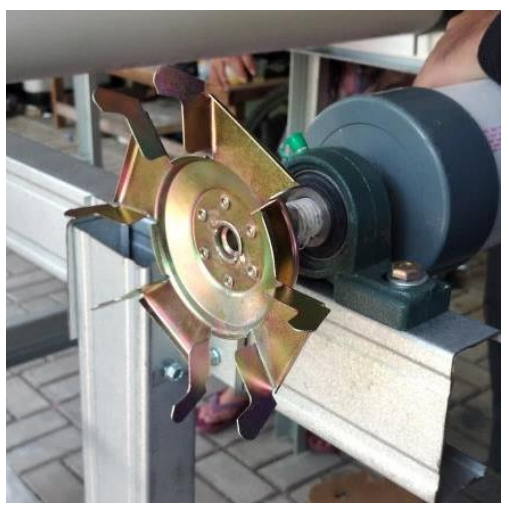

Gambar 5 (a). Pemasangan Pull

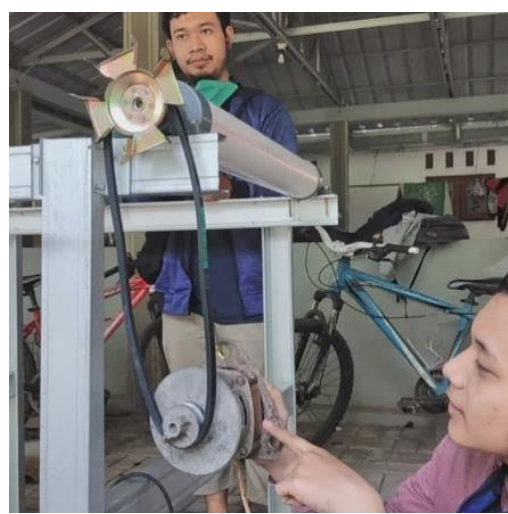

Gambar 4 (b). Pemasangan Generator dan v-belt

6. Pasang karpet mini konveyor secara kencang setelah itu mini konveyor sudah bisa dijalankan

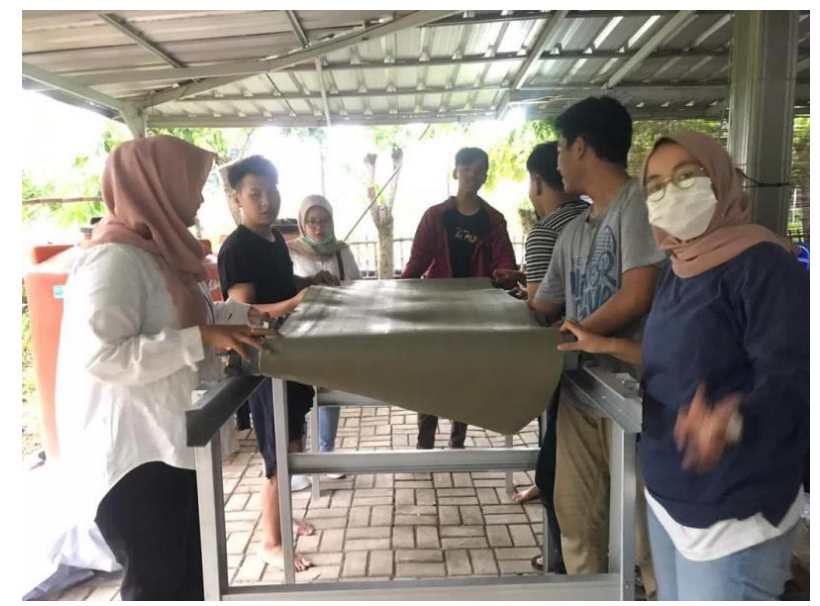

Gambar 6. Pemasangan Karpet Konveyor

7. Tempat untuk memasang kamera dibuat dengan menggunakan baja ringan yang ditempelkan ke badan konveyor lalu kamera dipasang diatasnya setelah pemasangan kamera maka mini konveyor sudah siap digunakan

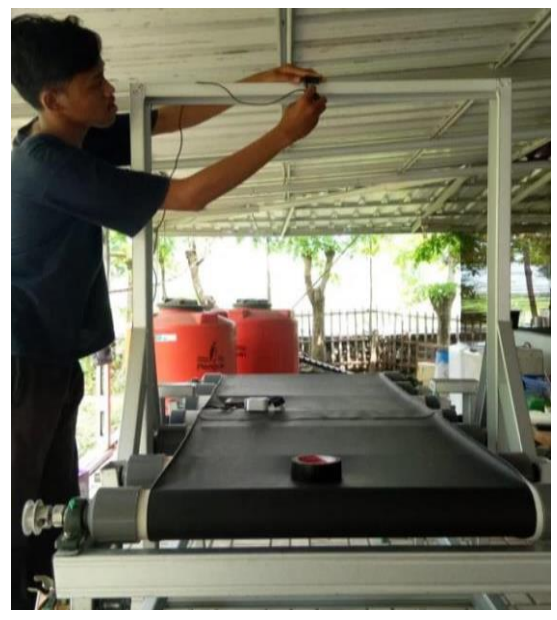

Gambar 7. Pembuatan Tempat untuk Kamera 


\section{HASIL DAN PEMBAHASAN}

Mini konveyor berbasis computer vision bertujuan untuk mempermudah dalam proses qualty control pada sebuah perusahaan terutama industri kecil dikarenakan tidak terlalu membutuhkan biaya yang terlalu besar dalam pembuatannya serta bahan-bahan yang digunakan dalam pembuatanya mudah ditemukan. Selain itu, dengan menggunakan mini konveyor berbasis computer vision dapat mempercepat prses quality control dan tidak menggunakan tenaga manusia didalamnya.

Konveyor dalam penggunaanya berfungsi untuk memindahkan bahan atau mengangkut bahan atau produk dari satu bagian kebagian lain (Utomo dkk., 2019). Pada mini konveyor ini konveyor berfungsi pada proses quality control yaitu untuk membawa kardus yang berisikan botol untuk melewati kamera pendeteksi.

Kamera pendeteksi dipasang diatas rangka mini konveyor. Kamera ini berfungsi untuk mendeteksi kardus yang melawatinya. Kardus tersebut berisikan botol yang jumlahnya sudah diatur terlebih dahulu. Untuk penelitian ini jumlah botol dalam kardus berjumlah 12 botol. Pada saat kardus melewati kamera kardus tersebut akan di deteksi dari gambar botol dalam kardus untuk mengecek jumlah botol dalam kadus tesebut sudah sesuai atau tidak.

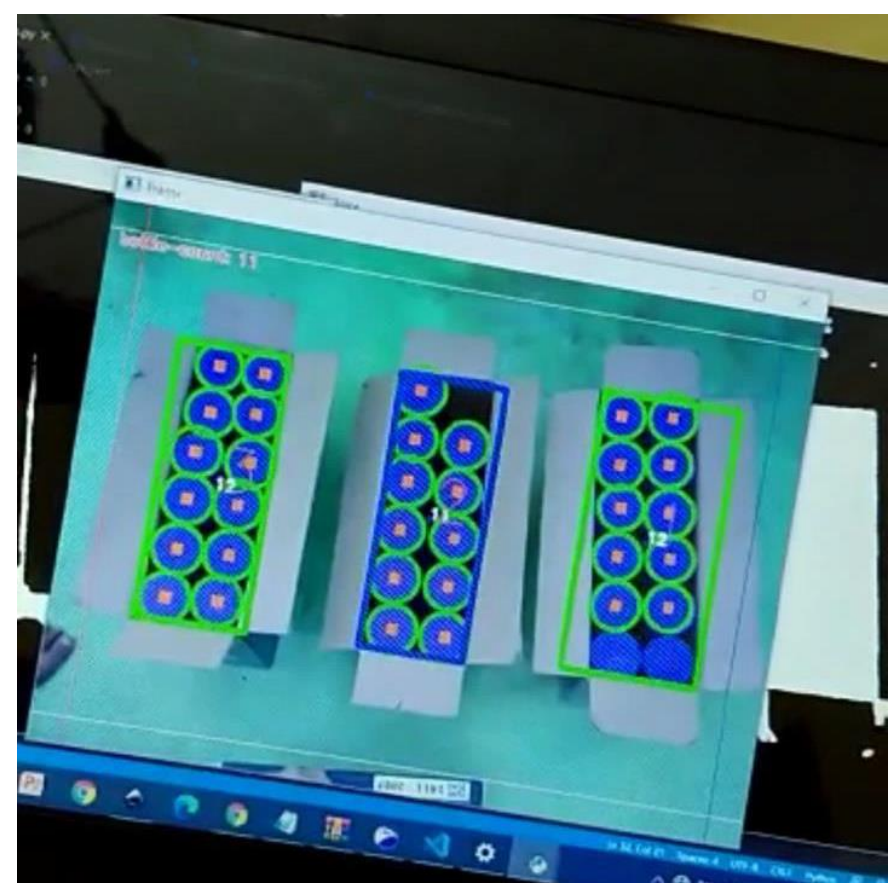

Gambar 8. Gambar yang ditangkap oleh kamera pendeteksi

Apabila terdapat kardus yang melewati kamera pendekteksi tersebut tidak sesuai dengan jumlah yang sudah ditentukan maka lampu LED yang dipasan diujung konveyor akan menyala. Menyalanya lampu LED tersebut digunakan sebagai ciri apabila terdapat kardus yang jumlahnya belum sesuai dengan jumlah yang sudah ditetapkan. Sebaliknya, apabila 
lampu LED tersebut tidak menyala maka kardus-kardus yang melewati kamera pendeteksi tersebut sudah sesuai dengan jumlah yang sudah ditentukan.

\section{SIMPULAN DAN REKOMENDASI}

Dengan adanya sistem otomasi akan mempermudah pekerjaan manusia salah satunya dengan penggunaan mini konveyor dengan sistem computer vision. Mini konveyor dengan sistem computer vision ini ditujukan untuk industri kecil untuk proses quality control. Dengan menggunakan sistem tersebut akan mempercepat dalam proses quality Control dan tidak menggunakan tenaga manusia didalamnya. Cara kerja dari mini konveyor berbasis computer vision adalah dengan membawa kardus melewati kamera pendeteksi sehingga dari gambar yang ditangkap akan didteksi jumlah botol dalam kardus tersebut sesuai atau tidak dengan jumlah yang sudah ditentukan. Apabila jumlah botol dalam kardus tersebut tidak sesuai maka lampu LED akan menyala.

\section{REFERENSI}

1. Dewantara, A. B., \& Kholil, M. (2017). Sistem Otomasi Sebagai Upaya Perbaikan Kualitas Dengan Metode Spc Pada Line Finishing (Studi Kasus: Pt. X). Jurnal Ilmiah Teknik Industri, 3(3), 141-149. https://doi.org/10.24912/jitiuntar.v3i3.465

2. Guntoro, G. B. (2020). Pemanfaatan Aplikasi Sebagai Media Bantu Edukasi Agama Islam Untuk Anak Usia Dini. Dinamisia : Jurnal Pengabdian Kepada Masyarakat, 4(1), 150-158. https://doi.org/10.31849/dinamisia.v4i1.3339

3. Jahary, M. M., Hannats, M., \& Ichsan, H. (2019). Implementasi Protokol Universal Plug and Play ( UPnP ) pada Sensor dan Aktuator untuk Otomasi Lampu. 3(7).

4. Limantara, A. D., Purnomo, Y. C. S., \& Mudjanarko, S. W. (2017). Pemodelan Sistem Pelacakan LOT Parkir Kosong Berbasis Sensor Ultrasonic Dan Internet Of Things (IOT) Pada Lahan Parkir Diluar Jalan. Seminar Nasional Sains dan Teknologi, 1(2), $1-10$.

5. Oktariawan, I., Sugiyanto, M., \& Fema, J. (2013). Pembuatan Sistem Otomasi Dispenser Menggunakan Mikrokontroler Arduino Mega 2560. 1(April), 18-24. 
6. Rachmat, H., Meidika, M. G., \& Atmaja, D. S. E. (2014). Perancangan User Requitment Specification (URS) Sistem Otomasi Proses Bottling Plant Pembuatan Air Minum Dalam Kemasan Botol 330 ML dan 600 ML di PT. XYZ. 147-153.

7. Rosi, I. N. (2017). Rancang bangun alat pembuat minuman kopi otomatis menggunakan konveyor. jurnal Ilmiah Mikrotek, 2(4), 35-45.

8. Santoso, A. B., Martinus, \& Sugiyanto. (2013). Pembuatan Otomasi Pengaturan Kereta Api, Pengereman dan Palang Pintu Pada Rel Kereta Apo Mainan Berbasis Mikrokontroler. 1, 16-23.

9. Utomo, S. N., Winarso, R., \& Qomaruddin, Q. (2019). Rancang Bangun Conveyor Mesin Planer Kayu Dengan Sistem Penggerak Motor Stepper. Jurnal Crankshaft, 2(1), 43-48. https://doi.org/10.24176/crankshaft.v2i1.3075

10. Wardani, A. K. (2015). Efektivitas Pelaksanaan Quality Control Pada Bagian Produksi Di Pt Indohamfish Di Pengambengan. Jurnal Jurusan Pendidikan Ekonomi, 5(1), 110. 